\title{
Redaksjonelt
}

\section{FORMakademisk med fortløpende publisering}

Ved slutten av 3. årgang av FORMakademisk, går vi nå et skritt videre når det gjelder å utnytte fordelene ved digital publisering. I forrige temanummer, Research by Design, publiserte vi artikler hvor videoer var integrert i teksten som illustrasjoner. I dette nummeret benytter vi muligheten til å publisere artiklene kontinuerlig. Dette gjør at tiden fra innsending, via fagfellevurdering til publisering av artikkel blir kortet ned. Forfatterne jobber i ulikt tempo, og nå slipper forfatterne å vente på at et visst antall artikler er klare samtidig. Denne utgaven av FORMakademisk er et åpent nummer, som vil speile noe av bredden innen forskningsfeltet design og designdidaktikk.

Erlend Vinje analyserer i den første artikkelen kritisk en tekst om baseskoler fra en internettside fra Rådgivningstjenesten for skoleanlegg i Utdanningsdirektoratet. I artikkelen beskriver han utviklingen av begrepsbruken knyttet til skoleanlegg med åpne løsninger, eller åpen skole som ble brukt på 70-tallet. Artikkelen konkluderer med at denne teksten ensidig vektlegger den ene av to konkurrerende diskurser.

Kristina Grange beskriver empirisk utviklingen fra laugsvesen til fremveksten av de moderne arkitekt- og ingeniørprofesjonene på slutten av 1800-tallet i sin artikkel. Hun fokuserer på utdanningssystemet som identitetsbygger for både arkitekters og ingeniørers profesjonelle identiteter. Artikkelen bygger på Foucaults teori om at makt og kunnskap forutsetter hverandre. Hun beskriver ytre hendelser som har bidratt til et teknisk-vitenskapelig kunnskapsideal, som fortsatt i dag er institusjonalisert i dagens utdanningssystem - og dermed påvirker mulige handlinger for arkitekter i dag.

Brynjar Olafsson og Gisli Thorsteinsson undersøker i sin artikkel bakgrunn, status og holdninger til design- og håndverksutdanning (Hönnun og smíði) i grunnskolen på Island. Deres hovedkonklusjon er at noen aspekter ved Design og håndverk må defineres nærmere for å styrke faget innen skolesystemet. Begreper er ikke klart definert og forskning innen faget mangler. Undersøkelsen viser at elevene er positivet til faget, men de mangler likevel forståelse av grunnleggende termer som kunst, design og håndverk. Design og håndverksutdanning i den islandske nasjonale læreplanen er ikke blitt realisert fullt ut. Forskningen viser at skolene ikke har fordelt ekstra timer til fagområdet, selv om lokale myndigheter la til rette for dette.

Per Galle ønsker i sin artikkel å bidra til utvikling av en felles designfaglig vitenskapsteori, som han mener mangler innen dette unge forskningsfeltet. En slik felles vitenskapsteori må ta hensyn til designfagenes egenart og bidra til deres selvforståelse. I artikkelen utvikler forfatteren et system av grunnleggende begreper, gjennom en filosofisk orientert begrepsanalyse. Begrepene design, forskning og designforskning analyseres i relasjon til begreper som viden, teori og praksis. Hensikten er å foreslå en presis, men samtidig intuitiv felles terminologi for å fremme forståelse og kommunikasjon på tvers av designfagene, som hvert av fagene så kan bygge videre på.

Kjetil Nordby og Andrew Morrison beskriver i sin artikkel hvordan SR-RFIDteknologi - Short-range Radio Frequency IDentification - innebygd i mobiltelefoner tilbyr praktikere innen interaksjonsdesign muligheten til å utforme nye former for opplevelser ved hjelp av mobiler. Artikkelen presenterer et designorientert forskningsprosjekt som søker å utvikle affordance - egenskaper ved objekter som signaliserer hva det kan brukes til, og som påvirker bruken - spesielt $i$ en slik praksis. Her drar forfatterne veksler på aktivitetsteori. Undersøkelsen åpner for en forståelse for å se SR-RFID som en teknologi som bidrar til at 
designere kan utforske potensielle nye interaksjonsmuligheter, ikke kun som funksjonalitet. Dette er viktig siden det kan brukes til å støtte generering av ny design, et område som ofte blir oversett i forskning på RFID, hevdes det i artikkelen.

Liv Merete Nielsen beskriver i den siste artikkelen endringer i kunst- og designfagenes plassering som skolefag i videregående opplæring i Norge i perioden 1976-1994. Perioden før 1994 omtaler hun som "husflidslinja", hvor kunst- og designfagene hadde gode rammer for utvikling, men elevene fikk ingen sluttkompetanse. Etter 1994 fikk det hun benevner hybriden Tegning, form og farge med studiekompetanse stor oppslutning, og ga kunst- og designfagene gode vilkår ved å gi både studiekompetanse og realkompetanse som grunnlag for opptak på høyere utdanning innen kunst, design og arkitektur. Imidlertid mener forfatteren at intensjonen fra 1976 om å kombinere teoretiske og praktiske fag er fulgt opp på yrkesfaglige studieretninger, men ikke på allmennfaglig studieretning.

Denne lederen er oppdatert fortløpende etter hvert som artiklene er publisert i løpet av høsten 2010.

Oslo, desember 2010

Janne Beate Reitan

Ansvarlig redaktør 